\title{
Silang Sengkarut Pembangunan Berkelanjutan Perkotaan Dalam Pusaran Kapital (Studi Kasus: Megaproyek Reklamasi CPI Makassar) Jurnal Ecces
}

\author{
Andi Faisal Anwar ${ }^{1}$ \\ Khairil Aswandi ${ }^{2}$ \\ 1,2, Program Studi Ilmu Ekonomi \\ Fakultas Ekonomi dan Bisnis Islam Universitas Islam Negeri Alauddin Makassar \\ Jl. Yasin Limpo, No. 36 Samata, Gowa, Sulawesi Selatan \\ E-mail :faisal.anwar@uin-alauddin.ac.id ${ }^{1}$, khairilaswandi@gmail.com²
}

\section{Abstrak: Silang Sengkarut Pembangunan Berkelanjutan Perkotaan Dalam Pusaran Kapital (Studi Kasus: Megaproyek Reklamasi CPI Makassar).}

Kebutuhan akan lahan di perkotaan kian hari kian meningkat, yang disebabkan peningkatan jumlah penduduk dan industrialisasi. Untuk memenuhi akan kebutuhan itu, maka salah satu cara yang bisa digunakan yaitu, dengan melakukan reklamasi kawasan pesisir. Termasuk proyek reklamasi yang berjalan di Kota Makassar yaitu, pembangunan megaproyek CPI (Centre Point of Indonesia) di Makassar. Akan tetapi, reklamasi itu nampaknya menimbulkan dampak sosial ekonomi dan kerusakan lingkungan yang cukup destruktif. Beranjak dari masalah inilah, peneliti ingin melihat apakah reklamasi tepat dijalankan dalam perspektif green economy. Penelitian ini berlokasi di Kelurahan Panambunga, Kecamatan Mariso, Kota Makassar. Metode analisis data yang digunakan dalam penelitian ini, yaitu metode kualitatif, dengan pendekatan studi kasus. Hasil yang didapatkan dalam penelitian ini antara lain, pembangunan perkotaan dengan melalui reklamasi itu tidak tepat dilakukan, karena sangat berdampak secara sosial dan lingkungan, termasuk penurunan pendapatan. Semuanya, menyimpang dari persyaratan pembangunan berkelanjutan. Pembangunan proyek reklamasi ini seringkali menimbulkan konflik dalam keluarga, oleh karena himpitan ekonomi, yang kian parah, yang disebabkan oleh menurunnya tingkat pendapatan, disaat yang sama terjadi peningkatan jumlah kebutuhan yang kian hari kian meningkat ditengah kompleksitas perkotaan. Sedangkan dampak ekonomi yang ditimbulkan berdasarkan hasil penelitian ini yaitu, terjadi penurunan drastis pendapatan nelayan sebelum dan selama pembangunan megaproyek reklamasi CPI Makassar tersebut. Dimana, pasca reklamasi terjadi penurunan pendapatan secara drastis, yang mengakibatkan menurun kualitas penghidupan masyarakat pesisir.

Kata Kunci: Green Economy, Reklamasi, Pendapatan. 


\section{Abstract: Cross Disputes of Sustainable Development Cities in The Capital Whirlpool (Case Study: Makassar CPI Reclamation Megaproject).}

The need for land in urban areas is increasing every day, which is caused by an increase in population and industrialization. To found these needs, one way that can be used is by conducting reclamation of coastal areas. Including the reclamation project that runs in Makassar, that is, the construction of a mega point CPI project (Center Point of Indonesia) in Makassar, but the reclamation seems to have a quite destructive social, economic and environmental impact. Moving on from this problem, researchers want to see whether reclamation is right carried out in a green economy perspective. The research is located in Panambunga Village, Mariso District, Makassar City. The data analysis method used in this study, namely the qualitative method, with a case study approach. The results obtained in this study include, urban development through reclamation is not appropriate, because it has a very social and environmental impact, including a decrease in income. Everything, deviates from the requirements of sustainable development. The construction of this reclamation project often leads to conflict within the family, due to the economic squeeze, which is getting worse, caused by declining income levels, while at the same time an increase in the number of needs is increasingly increasing amid urban complexity. While the economic impact caused based on the results of this study, namely, there has been a drastic decline in fishermen's income before and during the construction of the Makassar CPI reclamation mega project. Where, after reclamation there was a drastic decline in income, which resulted in a decline in the quality of livelihoods of coastal communities.

Keywords: Green Economy, Reclamation, Income.

\section{PENDAHULUAN / INTRODUCTION}

Kebutuhan akan pemenuhan lahan di daerah perkotaan kian hari kian meningkat, hal ini disebabkan oleh peningkatan jumlah penduduk dan proses industrialisasi yang berlangsung. Termasuk yang terjadi di Kota Makassar, sebagai kota yang berada di daerah pesisir, maka reklamasi dianggap perlu dilaksanakan untuk memenuhi akan kebutuhan lahan itu. Dalam hal ini pemerintah Kota Makassar mencanangkan pembangunan suatu proyek yang dikenal dengan megaproyek reklamasi CPI (Centre Point of Indonesia) Makassar. Namun, disaat yang sama pelaksanaan pembangunan proyek reklamasi itu, menimbulkan terjadinya berbagai kerusakan ekosistem, dengan fakta yang terjadi yaitu, secara ekstrim mengubah fungsi-fungsi ekologis di sepanjang pantai Makassar. Berbicara mengenai pertumbuhan penduduk, jumlah penduduk Kota Makassar, tahun 2015 berada di angka 1.449.401 jiwa, angka tersebut mengalami penambahan sebesar 20.200 jiwa pada tahun 2016 menjadi 1.469.601 jiwa, atau dengan laju pertumbuhan sekitar 1.39\%. Sedangkan tahun 2017 mengalami penambahan sebesar 19.410 jiwa, menjadi 1.489 .011 jiwa, atau 
dengan laju pertumbuhan sekitar 1.32\%. dan jika dilihat secara keseluruhan, kepadatan penduduk Kota Makassar tahun 2017 dengan luas daerah 175.77 km2 yaitu sebesar 8.471 jiwa per km2. Melihat data pertumbuhan dan kepadatan penduduk Kota Makassar sebagaimana yang dipaparkan di atas, dari tahun ke tahun di Kota Makassar mengalami peningkatan jumlah penduduk, yang artinya kebutuhan akan pemenuhan lahan juga kian meningkat. Oleh sebab itu, kembali ditekankan. Sebagai kota yang berada di pesisir pantai, reklamasi dianggap perlu dilaksanakan.

Pembangunan proyek reklamasi CPI Makassar, di dalamnya akan dibangun berbagai macam fasilitas, mulai dari pusat bisnis, wisata, pendidikan, hingga permukiman. Luas areal yang akan direklamasi mencapai $157 \mathrm{Ha}$, yang terdiri dari $50 \mathrm{Ha}$ milik pemerintah untuk fasilitas umum atau publik dan 107 Ha milik swasta sebagai kawasan bisnis. Namun, dari $107 \mathrm{Ha}$ tersebut 30\% akan dibuatkan fasilitas umum dan fasilitas sosial, seperti jalan, jembatan dan juga taman. Adapun data rincian fasilitas yang akan di bangun d kawasan CPI tersebut yaitu, pembangunan wisma negara, Makassar City Center, Masjid Indonesia Rahimakumullah, Museum 1000 Pahlawan Nusantara, Diplomat Village, Taman, dan prasarana lingkungan, sedangkan lahan milik swasta digunakan untuk pembangunan Sunset Golf Park seluas, Bussiness Park, Coral Park Garden, Mangrove Park, dan Clamshell Park. Melihat dari fasilitas yang akan dibangun, sangat jelas bahwa proyek reklamasi CPI Makassar condong pada pembangunan kawasan komersial, yang diharapkan nantinya akan mendatangkan keuntungan ekonomi bagi wilayah tersebut, dengan asumsi yang digunakan disini adalah semakin banyak kawasan komersial yang dibangun di daerah ataupun kota itu, maka dengan sendirinya juga akan menambah pendapatan asli daerah (PAD).

Reklamasi menimbulkan terjadinya berbagai kerusakan ekosistem yang secara ekstrim, mengubah fungsi-fungsi ekologis di sepanjang pantai Makassar. Adapun berbagai dampak ekologis yang dirasakan sekarang ini, antara lain akan menutup areal muara Sungai Jeneberang, sehingga dipastikan akan terjadi sedimentasi atau pengendapan lumpur yang terbawa arus sungai, dengan volume 30 juta kubik, dan jika hal ini berlangsung terus menerus, maka dampaknya terjadi pendangkalan pada perairan sekitar, termasuk perairan sekitar pelabuhan Kota Makassar, sehingga menimbulkan kompleksitas baru. Selain itu, proyek ini juga akan merusak daerah aliran Sungai Tallo. Dampak selanjutnya dari proyek 
Faisal, Khairil, Silang Sengkarut Pembangunan Berkelanjutan...

reklamasi CPI Makassar yaitu, menggangu pola arus laut (oceanografi),perubahan pola arus laut ini, akan memicu abrasi terhadap pulau-pulau yang terdapat di perairan Kota Makassar, selain itu pembangunan proyek reklamasi ini juga menggangu sirkulasi dan hidrologi air di sekitaran perairan yang berada dikawasan proyek tersebut, dan dapat dilihat langsung dengan kasat mata terutama di kawasan Pantai Losari, karena terganggunya sirkulasi dan hidrologi, menyebabkan air laut berwarna hitam yang bercampur lumpur, dengan bau yang cukup menyengat. Dipastikan biota laut, hampir tidak ada di sekitaran wilayah perairan ini.

Dampak selanjutnya, yaitu menghilangkan kawasan serapan air karena menjadi jalan utama lintas Metro Tanjung Bunga, yang merupakan akses menuju proyek reklamasi tersebut, sehingga tidak mengherankan pada saat musim hujan banjir kerap kali terjadi. Pembangunan jalan ini juga menghilangkan terumbu karang dan kawasan mangrove, yang dimana fungsi utamanya yaitu penyerap karbon lepasan kawasan industri, khususnya di daerah perkotaan, yang pada akhirnya menyebabkan hilangnya keanekaragaman hayati di perairan Makassar, sehingga akan berkonstribusi meningkatkan efek global warming. Selain itu akibat proyek reklamasi ini, juga menyisakan kawasan Tempat Pelelalangan Ikan di Rajawali sebagai kubangan dan tempat bertumpuknya sedimentasi. Adapun dermaga yang dulu berjejer perahu-perahu nelayan dari pagi hingga sore hari, itu sudah tidak nampak lagi. Dan sekarang kondisinya seperti kolam kecil dengan air berwarna hitam pekat.

Melihat dampak ekologi sebagaimana yang dipaparkan di atas, adapun dampak lain yang juga harus diperhatikan, yaitu dampak sosial ekonomi masyarakat di sekitar proyek reklamasi CPI Makassar yaitu, penurunan drastis hasil tangkapan bagi nelayan sekitar, hal ini sebabkan karena kerusakan ekosistem laut yang terkena dampak dari proyek reklamasi tersebut, seperti ikan, kepiting dan kerang sulit di dapat dibanding sebelum adanya proyek reklamasi tersebut. Dampak lain yang ditimbulkan yaitu semakin jauhnya area penangkapan nelayan sekitar, yang disebabkan oleh kerusakan ekosistem, sehingga berakibat kurangnya potensi perikanan dan ikan di perairan sekitar kabur, dan berpindah ke perairan pulau Barrang Lompo, perairan Maros, bahkan sampai ke perairan Pangkep.

Dampak selanjutnya yaitu perubahan akses untuk melaut bagi nelayan sekitar, yang disebabkan adanya penyempitan dan sedimentasi laut, dahulu rute nelayan untuk keluar pergi menangkap dari arah TPI Rajawali tidak begitu jauh, sekarang nelayan harus memutar untuk keluar masuk dari menangkap ikan, sehingga hal ini juga mengakibatkan biaya operasional pembelian bahan bakar semakin meningkat, selain itu akibat pendangkalan 
lautan juga menyebabkan nelayan yang dulunya bisa membongkar hasil tangkapannya dekat dengan tempat pelelangan. Saat kemarau, perahu dengan muatan ikan penuh bisa membongkar di luar dermaga, lain halnya sekarang ini, karena jalur kapal dangkal. Maka para nelayan hanya bisa membongkar hasil tangkapannya di halaman belakang Rumah Sakit Siloam.

Berdasarkan penjelasan di atas, melihat banyaknya dampak negatif yang ditimbulkan dari adanya proyek reklamasi. Ruslin (2017) mengemukakan bahwa pembangunan proyek reklamasi secara ekstrim mengubah fungsi-fungsi ekologi di sepanjang pantai, yang mengakibatkan terancamnya ekosistem pantai dan kehidupan sosial masyarakat sekitar. Karena kebiasaan buruk dalam pembangunan kita adalah mengakali Amdal. Idealnya, proyek pembangunan berdasarkan analisis dampak lingkungan, tetapi yang sering terjadi Amdal menyesuaikan pembangunan. Akhirnya amdal dikondisikan sesuai kehendak pemilik modal, yang sekaligus menegaskan praktik kapitalisasi semakin kuat dalam proyek reklamasi ini. Green Economy merupakan model pembangunan ekonomi yang berbasis pembangunan berkelanjutan, yang beroirientasi pada peningkatan aspek ekonomi, dengan tetap memperhatikan kelestarian lingkungan hidup, dan juga peningkatan kesejahteraan rakyat sebagai tujuan akhir kegiatan ekonomi. Selain itu Green Economy juga sebagai model pendekatan pembangunan ekonomi yang tidak lagi mengandalkan pembangunan ekonomi berbasis eksploitasi sumber daya alam dan lingkungan yang berlebihan, selain itu Green Economy juga merupakan suatu lompatan besar untuk meningkatkan praktik-praktik ekonomi yang mementingkan keuntungan jangka pendek yang telah mewariskan berbagai permasalahan yang mendesak untuk ditangani, termasuk di antaranya menggerakkan perekonomian yang rendah karbon (Low Carbon Economy).

Green Economy juga merupakan sebuah paradigma pembangunan yang perlu dikedepankan dalam rangka pemerintah melakukan kebijakan pengelolaan dan pemanfaatan sumber daya alam, untuk mencegah kerusakan lingkungan serta pengelolaan dan pemanfaatan sumber daya alam yang adil dan berkelanjutan. Oleh karena itu Green Economy perlu dimasukkan dalam perencanaan program pembangunan ekonomi. Akan tetapi sepanjang kebijakan pemerintah masih menjadikan tanah dan sumber daya alam sebagai bahan baku utama untuk menghasilkan devisa tanpa disertai upaya-upaya 
Faisal, Khairil, Silang Sengkarut Pembangunan Berkelanjutan...

perlindungannya, maka paradigma ekonomi hijau hanya sebatas slogan belaka. Mengingat pada kenyataannya, yang dominan menentukan adalah kepentingan ekonomi. Sedangkan kepentingan lingkungan selalu diletakan di bawah kepentingan ekonomi.

\section{TINJAUAN TEORITIK / LITERATURE REVIEW}

\section{Teori Sewa Tanah}

Teori sewa tanah menurut mahzab klasik para pemikir ekonomi pada mazhab klasik, diantaranya Adam Smith (1723-1790), David Ricardo (1772-1823), dan Thomas Robert Malthus (1766-1834) dan Karl Marx telah meletakkan landasan yang kuat bagi perkembangan ilmu ekonomi. Di dalamnya juga terdapat teori tentang sewa tanah yang satu sama lainnya mengandalkan beberapa pengertian dasar yang telah dipaparkan oleh para tokoh mazhab phsyokrat dan tokoh ekonomi klasik lainnya.

Menurut Adam Smith dalam Deliarnov (1995) yang terkenal dengan karyanya Wealth oh Nations, pembayaran uang terbesar untuk membiayai produksi dan distribusi adalah upah, sewa, dan laba. Mengenai sewa, Smith berpendapat bahwa sewa pada hakekatnya merupakan suatu harga monopoli. Luas tanah yang subur yang dibutuhkan itu terbatas jumlahnya, orang yang memilikinya dapat menarik bayaran tertentu pada para pemakai. Sewa itu bukan merupakan upah tenaga kerja maupun balas jasa bagi para pemilik modal atau investor. Sewa yang tinggi semata-mata akibat kekayaan nasional yang melimpah atau tingkat upah yang tinggi. Dalam analisisnya tentang sewa, Adam Smith telah merintis teori terkenal tentang Uneraned Increment (penghasilan bukan balas karya). Selanjutnya, dalam beberapa pemikiran yang terkandung dalam gagasan Adam Smith telah mengungkapkan bahwa imbalan jasa untuk penggunaan tanah tidak dianggap sebagai factor yang menentukan harga, melainkan sewa tanah merupakan residu, unsur residual (sisa hasil) dari harga barang tersebut. Bagian residu itu jatuh pada dan dinikmati oleh pemilik atau penguasa tanah. Menurutnya, sewa tanah bukan merupakan komponen dalam biaya produksi yang menentukan harga barang, melainkan tinggi rendahnya upah (beserta bunga dan laba) yang menjadi faktor yang menentukan tinggi rendahya harga barang. Sebaliknya, tinggi rendahnya sewa tanah merupakan sisa hasil dari harga barang itu (setelah dikurangi dengan biaya produksi). Dalam hubungan itu, oleh Adam Smith dengan mengandalkan pemikiran yang telah diungkapkan oleh Turgot sebelumnya yang juga ditunjukkan dengan 
perbedaan mutu lahan diantara berbagai bidang tanah yang digunakan dalam proses produksi.

Sebidang tanah tertentu akan menghasilkan lebih banyak dengan menggunakan pupuk dan tenaga kerja, tetapi sampai pada suatu titik tertentu tidak menguntungkan lagi menambah pupuk dan tenaga kerja tersebut, untuk meningkatkan produktivitas tanah. Kenaikan biaya lagi tidak akan menambah hasil secara proporsional, bahkan jika biaya ditambah terus, hasilnya malah akan berkurang. Imbalan jasa bagi penggunaan tanah dalam proses produksi dikaitkan dengan jumlah penduduk yang semakin bertambah dan permintaan meningkat terhadap sumber daya produksi untuk mempertahankan kehidupan manusia. Untuk itu, semakin banyak tanah diperlukan sedangkan di lain pihak bidang tanah yang mengandung mutu lahan yang subur senantiasa terbatas. Permintaan dan kebutuhan terus mendesak sehingga mau tidak mau tetap menggunakan tanah yang mutu lahannya semakin menurun. Bagian yang paling penting dalam pola dasar pemikiran Malthus dan kerangka analisisnya adalah menyangkut tentang teori sewa tanah dan tentang penduduk.

Pandangan itu ditentang oleh David Ricardo dalam Jones (1996) bahwa teori sewa tanah yang dianut Malthus, sejalan dengan teori yang dikembangkan oleh Ricardo, yaitu dengan berpangkal tolak pada Law of Diminishing Returns (LDR). Menurut Malthus harga pangan yang tinggi disebabkan karena sewa tanah yang tinggi dan sewa tanah yang tinggi disebabkan karena masyarakat kehadapatn lahan yang subur sebagai akibat penduduk yang semakin padat. Di zaman Turgot, ada anggapan umum seakan-akan berlakunya kecenderungan dalam LDR itu terbatas pada produksi pertanian. Oleh Malthus dijelaskan bahwa kecenderungan tersebut berlaku dalam penggunaan semua sumber daya alam. Oleh karena itu, menjadi semakin sukar untuk menyediakan sumber nafkah untuk kehidupan manusia secara wajar bagi penduduk yang makin bertambah.

David Ricardo dalam bukunya Principles of Political Economy and Taxation yang diterbitkan pada tahun 1817 memberikan perhatian utamanya pada masalah distribusi kekayaan karena dalam hal itu menurutnya penjelasan Smith maupun Malthus tidak terlalu memuaskan meskipun ia sendiri banyak belajar dari keduanya. Sewa tanah menurut Adam Smith merupakan suatu harga monopoli, Ricardo sependapat dengan Smith tetapi ia 
menguraikan lebih lanjut. Seandainya tanah berlimpah ruah jumlahnya seperti halnya udara, setiap orang asal mau mempunyai tanah dan pasti tidak ada harganya. Tanah akan menjadi "barang bebas", menurut Ricardo begitulah asal mulanya. Para petani yang pertama tentu memilih lahan yang paling subur. Akan tetapi, segera setelah lahan subur itu habis maka orang akan mengambil lahan yang tidak begitu subur. Semenjak itu, lahan yang subur mempunyai harga karena tiap jengkal memberikan hasil yang lebih banyak, sementara tidak ada lagi lahan yang seperti itu tersedia. Jika proses yang demikian itu berlangsung terus menerus, dan lahan yang kurang suburpun telah dimiliki orang maka harga lahan yang subur akan makin meningkat. Sewa atas tanah yang lebih subur, bukanlah pembayaran atau balas jasa bagi tenaga kerja, tetapi lebih merupakan pembayaran yang timbul hanya karena pemilikan suatu sumber daya alam yang langka. Pembayaran demikian itu oleh Ricardo dinamakan sewa tanah, bukanlah suatu balas jasa atau imbalan bagi faktor produksi. Barang siapa yang memiliki atau menguasai tanah yang mutu lahannya lebih baik dari pada tanah akhir di batas (land on the margin), mereka itu memperoleh rejeki berupa surplus di atas biaya. Surplus tersebut semakin besar dengan semakin baiknya mutu lahan. Dengan begitu, pihak yang memilki atau menguasai tanah yang subur, sebenarnya semacam menerima rejeki nomplok dari adanya tekanan kebutuhan dan permintaan yang semakin meningkat.

Teorinya tentang sewa tanah, Ricardo menjelaskan bahwa jenis tanah berbedabeda; ada yang subur, kurang subur, hingga yang tidak subur sama sekali. Produktivitas tanah yang subur lebih tinggi. Dengan demikian, untuk menghasilkan satuan unit produksi diperlukan biaya (biaya rata-rata dan biaya marginal) yang lebih rendah. Semakin rendah tingkat kesuburan tanah, jelas semakin tinggi pula biaya rata-rata dan biaya marginal untuk mengelolah tanah tersebut. Semakin tinggi biaya maka keuntungan per hektar tanah menjadi kecil pula. Melihat penjelasan di atas maka adalah layak jika sewa untuk tanah yang lebih subur lebih tinggi jika dibandingkan dengan tanah yang kurang subur. Meskipun Ricardo sependapat dengan Adam Smith bahwa harga alamiah untuk setiap barang didasarkan pada biaya tenaga kerja yang dikeluarkan untuk menghasilkan barang tersebut namun Ricardo tidak setuju jika sewa tanah dimasukkan ke dalam harga alamiah sebagai biaya produksi. Akan tetapi, Ricardo memasukkannya ke dalam harga alamiah biaya tenaga kerja yang dibutuhkan untuk membangun gedung dan mesin (modal). Oleh karena itu, dalam menerima keuntungan pemilik modal mengamnbil sesuatu yang dihasilkan tenaga kerja. Dengan demikian, menurut Ricardo terjadi konflik antara majikan dan buruh 
mengenai masalah pembagian keuntungan. Sewa pada hakekatnya mengurangi keuntungan. Dalam jangka panjang keuntungan cenderung menurun ke titik nol, sementara para tuan tanah akan memperoleh surplus tanpa harus bersusah payah bekerja untuk mendapatkannya.

David Ricardo telah mengembangkan pemikiran Adam Smith secara lebih terjabar dan juga lebih sistematis. Kerangka garis pemikiran Ricardo perihal teorinya tentang nilai dan harga serta teorinya tentang upah, juga konsekuen diterapkan dalam teorinya tentang sewa tanah. Hal itu masih dilengkapi dengan ikut memperhatikan berlakunya LDR yang dahulu diungkapkan oleh Turgot pada mazhab physiokrasi sebagai kecenderungan dalam produksi pertanian. Ricardo menyatakan bahwa meningkatnya sewa tanah adalah sebagai akibat kesulitan untuk menyediakan tanah dan pangan bagi penduduk yang bertambah. Kini terlihat bahwa LDR yang berawal dari pemikiran Turgot menjadi dasar dan pangkal tolak bagi teori sewa tanah oleh David Ricardo.

Hal itu disintesa oleh Marx dalam Muhammad (2013) bahwa Marx mempertanyakan penolakan Malthus untuk melihat perbedaan spesifik yang ia anggap ada dalam formasi sosial yang berbeda yang terjadi di tiap fase berbeda perkembangan sejarah. Dalam hal ini, Marx menekankan pentingnya memperhatikan perbedaan moda produksi sosial yang mendeterminasi perkembangan masyarakat yang kemudian mengkondisikan fenomena populasi-lebih. Konsekuensi dari pentingnya melihat perkembangan historis, membuat Marx harus melakukan pembongkaran atas rasio aritmatik yang menjadi pembenaran bagi keterbatasan sumber daya alam, untuk menopang pertumbuhan jumlah populasi. Dalam hal ini, Marx kemudian mengarahkan pertanyaannya pada problem sumber daya alam yang pada saat itu banyak dielaborasi oleh tradisi ekonomi klasik melalui teori sewa tanah. Pada titik ini, gagasan ekonom klasik seperti David Ricardo, masuk ke dalam diskusi teoritis Marx tentang ekologi karena kontribusinya terhadap perkembangan teori sewa tanah pada saat itu. Marx dan Ricardo sejalan ketika melihat kesalahkaprahan Malthus, dimana bukan jumlah benih yang menyebabkan terjadinya kelebihan populasi, akan tetapi tingkat pengangguran. Namun Marx mencatat poin dimana, menurutnya, teori sewa tanah Ricardo sama dengan teori Malthus, karena keduanya sama-sama tidak memberikan perhatian teoritis yang cukup pada dimensi perkembangan historis. Dari situ Marx kemudian mengalihkan pandangannya 
Faisal, Khairil, Silang Sengkarut Pembangunan Berkelanjutan...

pada teori sewa tanah, yang menurutnya lebih superior dibandingkan Ricardo dan Malthus. Sewa, menurut Marx dikenakan untuk penggunaan tanah yang lebih subur. Kurangnya kesuburan tanah pada saat penanaman hanya cukup untuk menutupi biaya produksi, sementara tanah yang lebih subur menciptakan sewa tanah yang lebih besar. Perbedaan mendasar Marx dibanding ekonom klasik sebelumnya adalah ia berpendapat bahwa tingkat kesuburan tanah ditentukan oleh perubahan historis seperti perkembangan teknologi dan cara produksi. Marx menambahkan, kegagalan untuk mendorong peningkatan kesuburan tanah lebih banyak disebabkan oleh kegagalan untuk mengadopsi praktik agrikultur yang rasional dan berkelanjutan. Penjelasan Marx, sekaligus mengakhiri tendensi ekonomi politik abad 18 dimana tanah masih dilihat sebagai hal yang terpisah dari historisitas perkembangan masyarakat.

\section{METODE PENELITIAN / METHODS}

Jenis penelitan yang digunakan adalah kualitatif, yang bersifat deskriptif, adapun pendekatan yang digunakan adalah pendekatan studi kasus. Lokasi penelitian berada di Kelurahan Panambungan, Kecamatan Mariso, Kota Makassar. Pengumpulan data yang dilakukan dalam penelitian ini yaitu dengan, wawancara, observasi, dan studi dokumen, yang dilakukan secara komprehensif, sampai diperoleh potret data yang kaya akan kasus yang diteliti. Pendekatan studi kasus ini, mengangkat pembangunan megaproyek CPI Makassar sebagai bahan kajian kasus berkaitan dengan pembangunan perkotaan dalam perspektif Green Economy, adapun dasar analisis dalam konsep Green Economy, yang menitikberatkan pada pembangunan berkelanjutan, dengan kesadaran manusia sebagai komponen utama dalam menyikapi masalah kerusakan lingkungan akibat dari aktifitas manusia itu sendiri.

Sedangkan dalam menganalisis dampak sosial ekonomi dari penelitian ini, yaitu menggunakan teori sewa yang dikemukakan oleh Adam Smith, Malthus, dan David Ricardo, yang menyatakan bahwa, produktifitas lahan berbanding lurus dengan sewa lahan tersebut. Selain itu, adapun data dalam penelitian ini diperoleh dari kajian buku, jurnal, daftar kuesioner, dan wawancara yang dilakukan di lokasi penelitian, yang telah di triangulasi. 


\section{HASIL DAN PEMBAHASAN / DISCUSSION}

\section{Pengaruh Pembangunan Megaproyek Reklamasi CPI Makassar terhadap Kehidupan Sosial Ekonomi Keluarga dan Masyarakat Pesisir.}

Kehidupan sosial keluarga dan masyarakat besar kaitannya dengan kesejahteraan, sedangkan kesejahteraan merupakan bentuk implementasi dari terpenuhinya kebutuhan akan sandang, papan, dan pangan. Nurma (1999), berdasarkan hasil wawancara terhadap informan maka diperoleh tanggapan mengenai Pengaruh pembangunan megaproyek reklamasi CPI Makassar terhadap Kehidupan Sosial Keluarga dan Masyarakat Sekitar.

Simon Takawaloeng mengafirmasi:

"Masalah dalam keluarga sering terjadi, sudah jelas karena dulu kita bagus penghasilan sekarang berkurang sekali, kalau hubungan dengan masyarakat biasa biasaji".

Berdasarkan tanggapan dari informan di atas dan semua informan yang diteliti, menyatakan hal yang sama yaitu, dengan adanya pembangunan megaproyek reklamasi CPI Makassar ini memberikan dampak pada kehidupan sosial keluarga, yang disebabkan karena himpitan ekonomi, yang kian hari kian meningkat, karena pendapatan semakin menurun, ditambah lagi tanggungan keluarga yang kebutuhannya, mau tidak mau harus dipenuhi, sehingga kerap kali menimbulkan berbagai masalah dalam rumah tangga. Selain daripada itu, adapun dampak terhadap kehidupan sosial bertetangga masyarakat sekitar menurut informan yang diwawancarai, yaitu mengatakan tidak ada pengaruhnya, terhadap kehidupan sosial bertetangga masyarakat sekitar.

Pembangunan megaproyek reklamasi CPI Makassar merupakan proyek besar, dan juga tidak dimunaffikan lagi, menimbulkan dampak yang besar pula bagi ekosistem dan masyarakat sekitar pada khususnya. Oleh karena itu, adapun harapan masyarakat sekitar jika nantinya pembangunan proyek tersebut sudah selesai dibangun. Seperti yang diutarakan Sapruddin Dg. Gassing menyampaikan bahwa:

"Yang pertama tama saya minta sebagai nelayan, belum sebagai penggusuran ini, saya minta dibelikan perahu, mesin yang besar, karena pencarian saya makin jauh tapi perahu saya tetap kecil, harus disediakan besar, makanya kalau badai gelombang itu kita taku keluar karna perahu ndag layak pakai, harus diganti kapal yang besar dan perahu yang besar, supaya kita itu bisa melaju keluar dari kampung kita mencari, sebagai korban penggusuran, beri kita modal sedikit, atau tempat tinggal yang layak,karena sampah saja ada tempatnya, tapi kenapa kita manusia tidak ada tempatnya". 
Berdasarkan tanggapan dari informan, mengemukakan mengenai harapan mereka jika pembangunan megaproyek reklamasi CPI Makassar ini selesai dibangun, mereka menginginkan bahwa, masyarakat amat sangat membutuhkan yang namanya kompensasi baik dari pihak pemerintah, ataupun dari pihak pengembang dalam hal ini pihak swasta. Kompensasi yang dimaksud, apakah itu dalam bentuk uang tunai, untuk modal usaha, ataukah bantuan berupa perahu atau mesin yang lebih besar, karena selama proyek ini dibangun, mereka tidak bisa lagi mencari ikan dipinggiran, karena perairan di pinggiran sudah sangat tercemar, sehingga ikan lari ke tengah laut, oleh karena itu mereka juga harus ke tengah laut untuk mencari hasil tangkapan, belum lagi kalau cuaca buruk, sedangkan perahu mereka kecil.

Masyarakat juga menginginkan, agar bisa dipekerjakan di sana, sesuai dengan janji dari pihak pengembang dan pemerintah. Agar mereka memperoleh pekerjaan yang layak. Dan adapun dari pihak korban penggurusan akibat pembangunan proyek reklamasi tersebut, menginginkan diberikan tempat tinggal yang layak, bukan diterlantarkan begitu saja, seperti yang dikatakan kembali Sapruddin Dg. Gassing, di akhir perkataannya:

"Sampah saja ada tempatnya, tapi kenapa kita manusia tidak ada tempatnya".

Dapat disimpulkan bahwa dampak sosial yang dirasakan masyarakat yaitu terkait dengan kehidupan berkeluarga, karena disebabkan oleh menurunnya tingkat pendapatan. Namun, terkait dengan kehidupan bertetangga dalam masyarakat sekitar, tidak ada dampak yang dirasakan, sebelum ataupun setelah pembangunan proyek reklamasi ini berjalan. Harapannya, jika proyek ini sudah selesai di bangun masyarakat meninginkan kompensasi dan juga penyerapan tenaga kerja bagi mereka yang terkena dampak.

Pembangunan reklamasi, tidak dapat dilepaskan dari dampak ekonomi yang ditimbukan bagi masyarakat nelayan sekitar. Oleh karena rusaknya ekosistem perairan yang berdampak pada kerusakan sumber daya perikanan, maka secara otomatis masyarakat sekitar berprofesi sebagai nelayan mengalami penurunan pendapatan, karena sulitnya mendapatkan hasil tangkapan. Yang pada akhirnya berimbas pada penghidupan masyarakat pesisir. Pekerjaan sebagai nelayan, merupakan pekerjaan dengan penghasilan tidak menentu, hal ini juga dirasakan oleh masyarakat nelayan sekitar di lokasi penelitian ini. Ditambah lagi dengan dibangunnya proyek reklamasi CPI Makassar, maka bisa dikatakan pekerjaan nelayan ini semakin berat untuk dijalani. Oleh karena itu adapun tanggapan informan berkaitan dengan pengaruh pembangunan proyek reklamasi ini, terhadap pekerjaan mereka. Simon Takawaloeng mengatakan: 
"Sangat berpengaruh, dulu kita mencari ikan santaiji, karena memang daerah sini banyak ikan, tp sekarang kebalikannya".

Berdasarkan hasil wawancara dari informan itu, mengafirmasi bahwa pembangunan megaproyek CPI Makassar ini, sangat mempengaruhi pekerjaan mereka, karena proyek ini sangat merusak ekosistem, jadi ikan yang sebagai tujuan tangkapan utama mereka lari keluar daerah yang terpapar kerusakan tersebut, karena bukan hanya proyek reklamasi CPI Makassar yang merusak habitat ikan, tapi yang turut andil dalam kerusakan perairan sekitar yaitu, pembangunan Pelabuhan Paotere, dan pembangunan pemecah ombak. Jadi bisa dikatakan, habitat ikan yang dahulunya di pesisir Pantai Makassar dikepung dan dirusak 3 proyek besar. Akhirnya, imbas dari pembangunan proyek tersebut, sangat dirasakan oleh nelayan pesisir sekitar karena sekarang ikan susah dicari, dan juga intensitas turun melaut mereka juga berkurang, beda dengan sebelum ada proyek reklamasi CPI Makassar ini, bisa dikatakan mereka hampir setiap hari melaut, belum lagi kalau cuaca buruk, mereka lebih pilih tinggal di rumah, karena kapal mereka yang kecil terus area penangkapan yang jauh, jika dipaksakan melaut, justru akan mengancam keselamatan mereka. Oleh karena itu, akibat Semakin susahnya memperoleh hasil tangkapan hingga ada informan yang mengatakan, yaitu Dg. Ngenta:

"Pembangunan CPI berpengaruh sekali, karna kita mau cari pekerjaan lain tidak bisa, karna tidak ada sekolah".

Seandainya terdapat pekerjaan lain yang bisa mereka kerjakan, dengan penghasilan yang jelas, maka mereka lebih memilih itu, dibanding tetap bertahan sebagai nelayan di tengah ketidakpastian yang mereka hadapi.

Hal itu juga dibenarkan oleh Sapruddin Dg. Gassing yang menyampaikan bahwa:

"yahh berpengaruh sekali, karena susami di dapat ikan di pinggiran-pinggiran, tapi haruski ke tengah lautki, itupun bensin pasti bertambah".

Berdasarkan hasil wawancara dari informan di itu, adanya pembangunan reklamasi CPI Makassar ini, sangat mempengaruhi pendapatan mereka sebagai nelayan sekitar. Selama pembangunan proyek ini berjalan, pendapatan nelayan menurun secara drastis, karena ikan makin susah dicari. Belum lagi, daerah tangkapan yang sudah sangat jauh, sehingga menyebabkan biaya pembelian bahan bakar juga kian meningkat, jika 
Faisal, Khairil, Silang Sengkarut Pembangunan Berkelanjutan...

dibandingkan keadaan sebelum dibangun proyek reklamasi ini, nelayan bisa menangkap ikan di pinggiran-pinggiran, karena pada saat itu ikan masih melimpah. Berbicara mengenai pendapatan nelayan setelah adanya pembangunan megaproyek reklamasi CPI Makassar, ada tanggapan dari salah satu informan, yaitu pak Ibrahim yang mengkonfirmasi hal-hal berikut:

"Aduh jelas skali pendapatan menurun pak, 100\% merugikan merugikan skali itu CPI".

Besarnya dampak dari pembangunan megaproyek reklamasi CPI Makassar, bisa dikatakan sangat menyengsarakan masyarakat sekitar, khususnya masyarakat nelayan, seringkali tangkapan yang mereka dapat hanya cukup untuk dikonsumsi saja, tapi tidak mampu menambah pendapatan nelayan. Nelayan pesisir di daerah yang terkena dampak dari pembangunan megaproyek reklamasi CPI Makassar, bisa dikatakan bahwa mereka menggantungkan hidupnya di tengah ketidakpastian, karena proyek reklamasi tersebut, sebagaimana yang sudah dipaparkan di atas, pendapatan nelayan sebelum dan setelah proyek ini, sangat jauh berbeda. Oleh karena itu, peneliti ingin membandingkan pendapatan nelayan sebelum dan selama pembangunan proyek reklamasi ini berjalan, dengan menggunakan analisis komparasi pendapatan. Hal itu dapat dilihat dari tabel biaya biaya yang dikeluarkan untuk melaut, dengan hitungan per trip (sekali turun melaut).

Tabel. 1.Biaya Melaut Sebelum dan Selama Proyek Reklamasi CPI Makassar Berjalan

\begin{tabular}{|l|c|c|r|}
\hline \multicolumn{1}{|c|}{ NAMA } & $\begin{array}{c}\text { BIAYA MELAUT } \\
\text { SEBELUM REKLAMASI/TRIP }\end{array}$ & $\begin{array}{c}\text { BIAYA MEAUT } \\
\text { SELAMA PEMB. REKLAMASI/T RIP }\end{array}$ & $\begin{array}{c}\text { PERSENTASE } \\
\text { KENAIKAN BIAYA MEAUT }\end{array}$ \\
\hline Simon Takawal oeng & $\mathbf{5 6 , 7 5 0}$ & $\mathbf{1 1 2 , 4 0 0}$ & $49.51 \%$ \\
\hline Dg. Ngenta (Oskar) & $\mathbf{2 9 , 0 0 0}$ & $\mathbf{8 0 , 8 5 0}$ & $64.13 \%$ \\
\hline Ansyar Dg. Lila & $\mathbf{2 2 , 0 0 0}$ & $\mathbf{6 7 , 7 5 0}$ & $67.53 \%$ \\
\hline Sapruddin Dg. Gassing & $\mathbf{2 2 , 2 5 0}$ & $\mathbf{6 4 , 8 2 5}$ & $65.68 \%$ \\
\hline Dg. Bollo & $\mathbf{2 7 , 2 5 0}$ & $\mathbf{4 8 , 1 0 0}$ & $43.35 \%$ \\
\hline Dg. Nuru (Pendos) & $\mathbf{2 2 , 2 5 0}$ & $\mathbf{6 8 , 1 0 0}$ & $67.33 \%$ \\
\hline Ibrahim & $\mathbf{4 4 , 0 0 0}$ & $\mathbf{1 0 2 , 7 5 0}$ & $57.18 \%$ \\
\hline John Hasen & $\mathbf{2 6 , 5 0 0}$ & $\mathbf{2 9 , 8 3 5}$ & $11.18 \%$ \\
\hline JUMLAH & $\mathbf{2 5 0 , 0 0 0}$ & 574,610 & $56.49 \%$ \\
\hline RATA RATA & $\mathbf{3 1 , 2 5 0}$ & $\mathbf{7 1 , 8 2 6}$ & $56.49 \%$ \\
\hline
\end{tabular}

Sumber: Hasil Olah Data Primer, 2019.

Berdasarkan tabel di atas, dapat kita lihat bahwa ada perbedaan biaya melaut, sebelum dan selama proyek reklamasi itu berjalan, dimana terjadi peningkatan drastis pada biaya melaut, adapun komponen dalam biaya melaut yang peneliti hitung yaitu, BBM, konsumsi, rokok, dan biaya biaya lainnya, atau rinciannya bisa di lihat di lampiran. Peningkatan biaya tersebut dengan patokan sesuai dengan yang didapat dari informan. Kenaikan biaya dengan presentase terendah yakni dengan capaian 11,8\%. Sedangkan adapun peningkatan biaya melaut paling tinggi yalni mencapai $67.53 \%$. 
Dengan demikian, biaya melaut secara keseluruhan mengalami peningkatan diberbagai level, hal ini disebabkan karena semakin jauhnya jarak tempuh nelayan mencari ikan, seperti yang dikatakan bapak ibrahim:

"Sebelum ada reklamasi, kita melaut paling jauh pulau kayangan sekarang ini bahkan ada yang sampai pangkep".

Selama proyek reklamasi ini berjalan area penangkapan ikan kian jauh, yang dulunya di pinggiran, mereka sudah bisa mendapatkan hasil tangkapannya, akan tetapi sekarang harus keluar ke pulau barrang lompo, perairan maros, bahkan sampai ke perairan Pangkep, akibat makin jauhnnya area tangkapan, secara otomatis meningkatkan penggunaan bahan bakar untuk melaut, yang berdasarkan data yang diperolehya dari informan, dengan rata rata, sebelum adanya reklamasi, hanya menggunakan bahan bakar sekitar 1.2 liter, sedangkan untuk sekarang ini, mereka harus menggunakan bahan bakar minimal 4 liter. Tidak hanya itu, selama proyek reklamasi ini berjalan, dulu jalur akses perahu nelayan keluar masuk melaut menuju ke TPI Rajawali tidak terlalu jauh, akan tetapi sekarang ini, mereka harus memutar untuk keluar melaut, dan itulah juga yang menambah biaya operasional mereka.

Berbicara mengenai keuntungan dari pembangunan megaproyek reklamasi CPI Makassar tersebut, dengan melihat besarnya kerusakan yang ditimbulkan, adapun tanggapan informan terkait benefit yang didapatkan dari reklamasi. Ansyar Dg. Lila mengatakan:

"Tidak ada sama sekali keuntungannya, hancur total, karna memang dampaknya begitu untuk nelayan, dulunya dekat mencari, kalo sekarang jauh sampai 2 jam, 3 jam dari pesisir, dulu Cuma 5 menit di situ kita suda dapat uang".

Melihat tanggapan dari informan, bahwa sampai saat ini sama sekali tidak ada keuntungan yang diperoleh masyarakat nelayan sekitar, melainkan kerugian besar yang didapatkan, bahkan juga kompensasi bagi yang masyarakat terkena dampak belum ada sama sekali, beda halnya dengan pembangunan paotere, menurut informasi yang diperoleh peneliti, setiap kepala keluarga mendapatkan kompensasi sekitar Rp. 20.000.000. Masyarakat sekitar juga sudah melakukan upaya pengaduan supaya mereka mendapatkan kompensasi, akan tetapi sampai sekarang belum ada respon dari pemerintah ataupun pengembang, dalam hal ini pihak swasta, seperti yang dikatakan Dg. Nuru (Pendos): 
Faisal, Khairil, Silang Sengkarut Pembangunan Berkelanjutan...

"Tidak ada, mereka kayak mo lepas tangan".

Terlepas daripada itu, mereka (para nelayan) tetap akan memperjuangkan hak mereka. Melihat tanggapan informan baik mengenai pekerjaan, penghasilan, ataupun keuntungan yang diperoleh masyarakat sekitar selama pembangunan megaproyek reklamasi CPI Makassar ini, dapat disimpulkan bahwa selama pembangunan proyek ini dampak ekonomi yang dirasakan masyarakat sekitar sangat besar, utamanya pada penurunan pendapatan yang drastis, yang diakibatkan oleh sulitnya memperoleh hasil tangkapan. Bahkan, masyarakat belum merasakan sama sekali penaganan pasca reklamsi untuk perbaikan penghidupan yang lebih baik.

\section{KESIMPULAN / CONCLUSION}

Sesuai dengan penjelasan di atas, melihat fakta di lapangan dan tanggapan informan yang diambil sebagai objek penelitian, dalam kaitannya dengan pembangunan perkotaan dalam pespektif green economy, dengan mengangkat pembangunan megaproyek reklamasi CPI Makassar sebagai bahan acuan, pelaksanaan proyek reklamasi tidak tepat dilakukan, karena sangat banyak dampak yang ditimbulkan dari pembangunan tersebut, baik dampak sosial, ekonomi, lingkungan, atupun penurunan kesejahteraan yang terjadi. Cukup bertentangan dengan prinsip pembangunan berkelanjutan dalam konsep green economy. Dampak atau pengaruh pembangunan megaproyek reklamasi CPI Makasaar terhadap perekonomian masyarakat sekitar yaitu terjadi penurunan pendapatan yang drastis, yang diakibatkan oleh sulitnya memperoleh hasil tangkapan. Dan juga sampai saat ini, masyarakat belum merasakan sama sekali keuntungan dari pembangunan megaproyek reklamasi CPI Makassar tersebut.

Adapun pendapatan masyarakat, mengalami penurunan akibat proyek reklamasi tersebut, dengan gambaran yang diperoleh berdasarkan hasil perhitungan analisis pendapatan, yaitu sebelum pembangunan megaproyek reklamasi CPI Makassar mengalami peningkatan yang drastis. Selama proyek ini dibangun, total pendapatan masyarakat mengalami penurunan yang sangat drastis. Adapun dampak sosial dari pembangunan proyek reklamasi ini yaitu berdampak pada kehidupan keluarga, oleh karena himpitan ekonomi, yang kian parah, yang disebabkan oleh menurunnya tingkat pendapatan, yang diikuti dengan peningkatan jumlah kebutuhan yang kian hari kian meningkat, beranjak dari situlah konflik dalam rumah tangga kerap kali terjadi. Selain itu adapun harapan masyarakat berkaitan dengan kesejahteraan masyarakat sekitar, jika proyek ini sudah selesai dibangun yaitu, mereka berharap ada kompensasi, bantuan, ataupun penyerapan tenaga kerja bagi 
meraka yang terkena dampak. Dengan demikian, pembangunan proyek reklamasi CPI Makassar selain berdampak pada perekonomian masyarakat sekitar, ternyata pembangunan proyek reklamasi tersebut juga berdampak pada rawannya terjadi konflik dalam keluarga, yang disebabkan turunnya tingkat pendapatan yang drastis. Oleh karena itu, pemerintah dan pihak pengembang (swasta) harus menyadari hal tersebut.

\section{DAFTAR PUSTAKA / REFERENCES}

Ruslin, Ismah Tita. 2017. Sualtern dan Kebijakan Pembangunan Reklamasi Pantai di Kota Makassar. Jurnal Politik Profetik. 5(2): 185-199.

Jones, P. 2016. Pengantar Teori-Teori Sosial dari Teori Fungsionalisme Hingga Post Modernisme. Jakarta: Pustaka Obor.

Ridha, Muhammad. 2013. Ekologi Marx sebagai Hubungan Metabolik antara Manusia dan Alam. Indoprogress.

Badan Pusat Statisik Provinsi Sulawesi Selatan. 2018. Sulawesi Selatan. 